\title{
Professor Raghu Nath Singh
}

\author{
Rafael Fernández Rubio ${ }^{1}$
}

Published online: 30 August 2021

๑) Springer-Verlag GmbH Germany, part of Springer Nature 2021

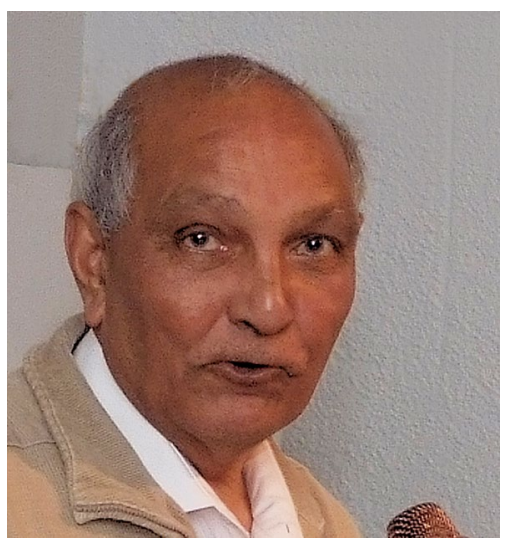

Prof. Raghu Nath Singh, at the IMWA Conference in Sydney, Nova Scotia, Canada (courtesy IMWA 2010)

Professor Raghu Nath Singh, one of the six founders of the International Mine Water Association (IMWA), passed away in Nottingham, UK on December 31, 2020, at the age of 81. After participating in the September 1978 Symposium on Water in Mining and Underground Works in Granada (Spain) and in May 1979 in the First International Mine Drainage Symposium in Denver (USA), he attended IMWA's inaugural meeting in Granada in November 1979. From the very beginning, he took on with full enthusiasm the task of propagating this association worldwide. His enthusiasm and great knowledge in conjunction with mining hydrogeology and rock mechanics contributed to many IMWA meetings in different countries around the world. He wrote many relevant articles, both in our journal and in the congresses and symposia of our association, of which he was a regular, contributing attendee. These are listed at the end of this obituary.

Rafael Fernández Rubio

rfrubio@gmail.com

1 School of Mining Engineering, Madrid Polytechnic University, Luna 45, 28120 Ciudad Santo Domingo, Madrid, Spain 
at the University of Nottingham. I particularly remember enjoying the company of Prof. Barry Whittaker, Prof. Raghu N. Singh, and Peter Norton, including time spent in what is claimed to be the oldest pub in England (the Ye Olde Trip Jerusalem, under Nottingham Castle) with its legends of the Crusader era.

On retirement, he returned from Australia to Nottingham with his wife, Cathy. His last attendance at an IMWA meeting was at the IMWA 2010 conference in Sydney, Nova Scotia, Canada, where he told me how difficult it was to attend, as he no longer had support from the University. Still, he was very happy to be there, among his many friends and colleagues.

Raghu was always a family man, coming from a large family in India where he was the second of five siblings. When his uncle died, his parents adopted their uncle's five children, and each was loved and looked after equally. And this, I think, marked his life in the purest concept of brotherhood, which he later universalized with his friends. Cathy was able to arrange a final mass gathering of his sons, their wives, and partners, and all his grandchildren to celebrate Raghu's 80th birthday, which was unforgettable for Raghu.

Prof. Raghu N. Singh for me fulfils the ideal of a professor. He combined his deep practical professional experience in mine operation with excellent scientific, teaching, and research skills. But behind all these fond and extraordinary memories, his is a story that deserves to be remembered, and I have done so here with the support of his most direct relatives and especially his oldest son Hemendra. I endorse the words of Ray Tolhurst, in an obituary published by the University of Wollongong: "Raghu will be missed by his friends ... throughout the wider mining industry, where he contributed a great deal". Let me add for my part that he contributed greatly to IMWA during his lifetime. Raghu: rest in peace, my friend forever! Your friends at IMWA will not forget you.

\section{Publications of Ragu Singh in the IMWA Journals Between 1982 and 2013 (Provided by Christian Wolkersdorfer)}

Aston TRC, Singh RN (1982) A new approach for determining permeability characteristics of rock using slug testing techniques. Int J Mine Water 1(3):33-42

Aston TRC, Singh RN (1983) A reappraisal of investigations into strata permeability changes associated with longwall mining. Int J Mine Water 2(1):1-14

Aston TRC, Singh RN, Whittaker BN (1983) The effect of test cavity geology on the in situ permeability of coal measures strata associated with longwall mining. Int J Mine Water 2(4):19-34
Atkins AS, Singh RN (1982) A study of acid and ferruginous mine water in coal mining operations. Int J Mine Water 1(2):37-57

Bridgwood EW, Singh RN, Atkins AS (1983) Selection and optimisation of mine pumping systems. Int J Mine Water 2(2): $1-18$

Doulati Ardejani F, Sadeghiamirshahidi M, Singh RN, Kish TE, Reed SM (2013) Prediction of the groundwater rebound process in a backfilled open cut mine using an artificial neural network. Mine Water Environ 32(4):251-257. https://doi.org/10.1007/s10230-013-0243-7

Doulati Ardejani F, Singh RN, Baafi E, Porter I (2003) A finite element model to: 1. Predict groundwater inflow to surface mining excavations. Mine Water Environ 22(1):31-38. https://doi.org/10.1007/s102300300005

Doulati Ardejani F, Singh RN, Baafi E, Porter I (2003) A Finite element model to: 2. Simulate groundwater rebound problems in backfilled open cut mines. Mine Water Environ 22(1):39-44

Fawcett RJ, Hibberd S, Singh RN (1984) An appraisal of mathematical models to predict water inflows into underground Coal Workings. Int J Mine Water 3(2):33-54

Fawcett RJ, Hibberd S, Singh RN (1986) Analytic calculations of hydraulic conductivities above longwall coal faces. Int J Mine Water 5(1):45-60

Fernández-Rubio R, Singh RN (1983) Slope stabilisation using advance dewatering techniques in a large opencast mine in north-western Spain. Int J Mine Water 2(4):35-51

Indratna B, Singh RN (1994) Distinct element analysis of water inflow to underground excavations. Mine Water Environ 13(3-4):11-24

Ngah SA, Reed SM, Singh RN (1984) Ground Water problems in surface mining in the United Kingdom. Int J Mine Water 3(1):1-12

Reed SM, Singh RN (1986) Groundwater recovery problems associated with opencast mine backfills in the United Kingdom. Int J Mine Water 5(3):47-73

Shi L, Singh RN (2001) Study of mine water inrush from floor strata through faults. Mine Water Environ 20(3):140-147. https://doi.org/10.1007/s10230-001-8095-y

Singh RN (1983) Conference review-hydrogeological aspects of mining. Int J Mine Water 2(2):31-32

Singh RN (1983) Mine water abstracts. Int J Mine Water 2(2):43-61

Singh RN (1986) Mine inundations. Int J Mine Water 5(2):1-27. https://doi.org/10.1007/BF02498098

Singh RN, Atkins AS (1982) Design considerations for mine workings under accumulation of water. Int J Mine Water 1(4):35-56

Singh RN, Atkins AS (1984) Application of analytical solution to simulate some mine inflow problems in underground coal mining. Int J Mine Water 3(4):1-27 
Singh RN, Hibberd S, Fawcett RJ (1986) Studies in the prediction of water inflows to longwall mine workings. Int J Mine Water 5(3):29-45

Singh RN, Jakeman M (2001) Strata monitoring investigations around longwall panels beneath the cataract reservoir. Mine Water Environ 20(2):55-64. https://doi.org/10. 1007/s10230-001-8083-2

Singh RN, Reed SM (1988) Mathematical modelling for estimation of minewater inflow to a surface mining operation. Int J Mine Water 7(3):1-33

Singh RN, Sivakumar M, Atkins AS (1995) Application of executive information system to mine site water pollution control. Mine Water Environ 14(1-4):95-105

Sivakumar M, Singh RN, Morton SGS (1992) Mine water effluent quality in the Illawarra Region. Mine Water Environ 11(2):1-10
Sivakumar M, Singh RN, Morton SGS (1994) Mine water management and controls in an environmentally sensitive region. Mine Water Environ 13(1):27-39

Terezopoulos NG, Singh RN (1987) Ground water control be grouting in tunnels for a pumped storage scheme. Int J Mine Water 6(1):33-48

Vutukuri VS, Singh RN (1993) Recent developments in pumping systems in underground metalliferous mining. Mine Water Environ 12(1-4):71-94

Vutukuri VS, Singh RN (1995) Mine inundation-case histories. Mine Water Environ 14(1-4):107-130. https://doi. org/10.1007/BF02914857 